\title{
URINARY EXCRETION OF AMINO ACIDS IN PATIENTS WITH CIRRHOSIS OF THE LIVER AND IN NORMAL ADULTS 1,2
}

\author{
By GEORGE J. GABUZDA, JR., 8 RICHARD D. ECKHARDT,4 AND \\ CHARLES S. DAVIDSON \\ (From the Thorndike Memorial Laboratory, Second and Fourth Medical Services (Harvard), \\ Boston City Hospital, and the Department of Medicine, Harvard Medical School, \\ Boston, Mass.)
}

(Submitted for publication July 25, 1952; accepted August 28, 1952)

\begin{abstract}
Although the liver occupies an important position in protein and amino acid metabolism, abnormalities in the metabolism of these nutrients by patients with severe hepatic diseases have been difficult to define. Alterations in the excretion of some amino acids, however, have been reported in patients with liver disease $(1,2)$. That these patients deviate from the normal with regard to the metabolism of certain individual amino acids also has been observed. For example, the finding of tyrosine and leucine crystals in the urine is considered an indication of severe liver disease, especially "acute yellow atrophy" (3), and abnormalities in the utilization and excretion of administered tyrosine $(4,5)$, methionine $(6)$, and glycine (7) have been reported.

This study presents data concerning the urinary excretion of the eight amino acids essential for adult man (8) and of arginine and histidine in 20 patients with cirrhosis of the liver as compared to 14 normal individuals maintained on diets and other conditions of study which were comparable.
\end{abstract}

\section{MATERIALS AND METHODS}

The twenty patients studied had advanced cirrhosis of the liver, associated in most instances with chronic alcoholism and decreased food in-

1 This work was done under the sponsorship of the Commission on Liver Disease, Armed Forces Epidemiological Board, and was supported in part by the Office of the Surgeon General, Department of the Army, and by a grant from Merck \& Co., Inc., Rahway, New Jersey, to Harvard University.

2 A preliminary report of this investigation appeared in the Proceedings of the National Meeting of the American Federation for Clinical Research, Atlantic City, New Jersey, May 4, 1952.

3 Welch Fellow in Internal Medicine of the National Research Council.

4 Present address: Veterans' Administration Hospital, Iowa City, Iowa. take. Evidence for severe liver disease was derived from the clinical history, physical examination, and liver function tests as well as liver biopsy or necropsy examination in some patients (Table I). The duration of the liver disease varied considerably. Some patients followed a course of slow improvement, and others chosen for special studies outlined below improved more promptly. The normal subjects were house officers and medical students in good health.

The patients were studied on the Thorndike Metabolic Ward where complete urine collection and dietary control were maintained. The daily food intake provided from 2,000 to 3,200 calories, and was considered adequate in other dietary essentials (except protein in some cases as indicated below). No supplements of methionine, choline, or vitamins were given to these patients during the studies (except patient F. C. who received a multivitamin capsule daily).

Three methods of study were employed. First, the daily urinary excretion of the ten "essential" amino acids was determined in 20 patients with cirrhosis of the liver and in 14 normal individuals maintained on comparable diets. Second, the effect of an increase in dietary protein intake upon the urinary excretion of these amino acids was observed in four of the patients (F. C., R. H., A. C., J. M.). During these studies the patients were given constant daily diets, and in successive metabolic periods of from six to nine days, increases in protein intake were made. In these cases the pooled urine obtained during the last three days of each study period was used for amino acid analysis in order to exclude the period of adjustment due to the change in the protein content of the diet. Finally, the effect of the severity of the liver disease upon the urinary excretion of the ten amino acids was noted in three patients (M. L., M. S., and J. S.). These patients were given con- 
TABLE I

Clinical and laboratory data in patients with cirrhosis of the liver

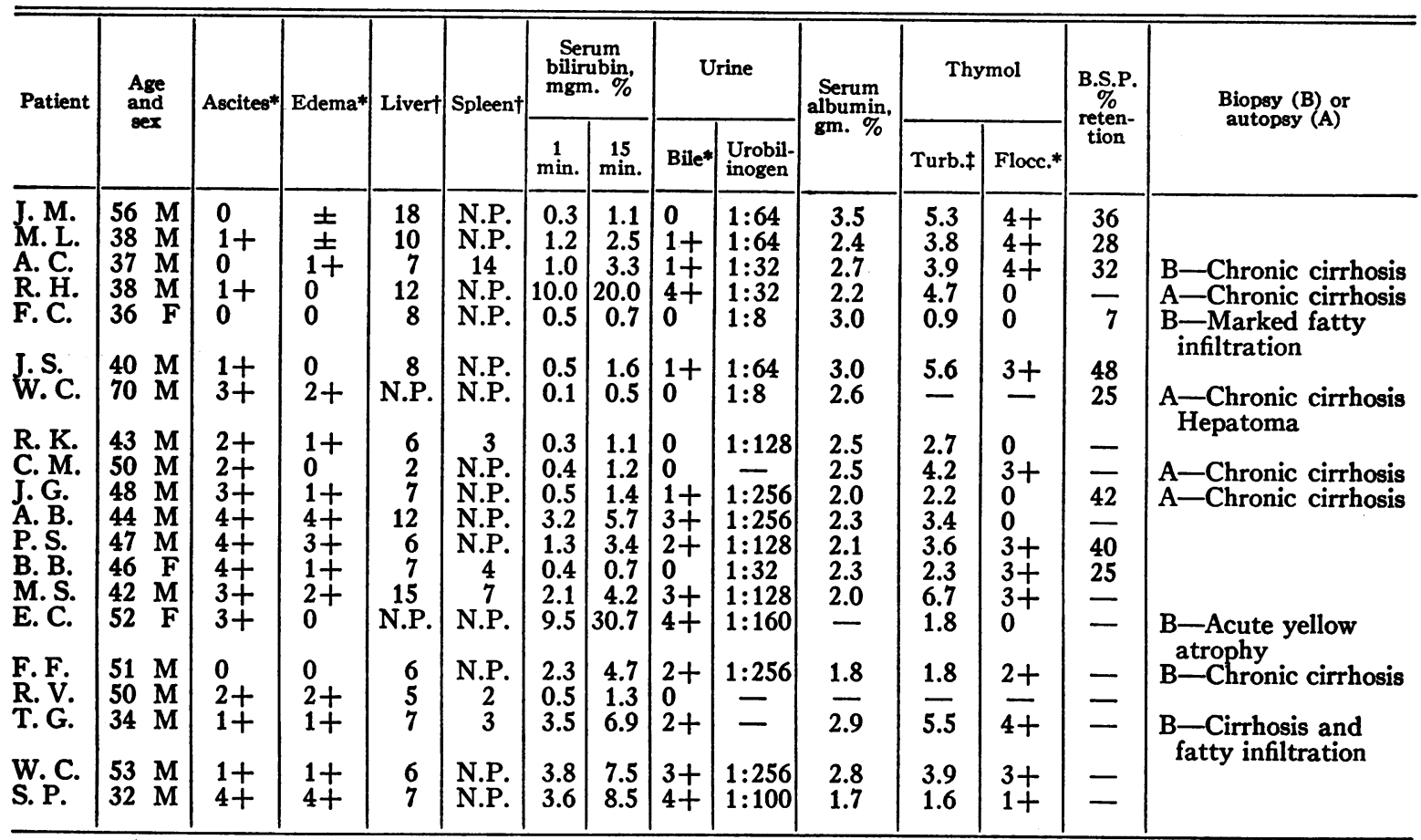

$0-4+$.

† Cm. below costal margin. $\ddagger$ Normal value $<1.7$ cc. $\mathrm{BaSO}_{4}$ suspension.

N.P. Not palpable.

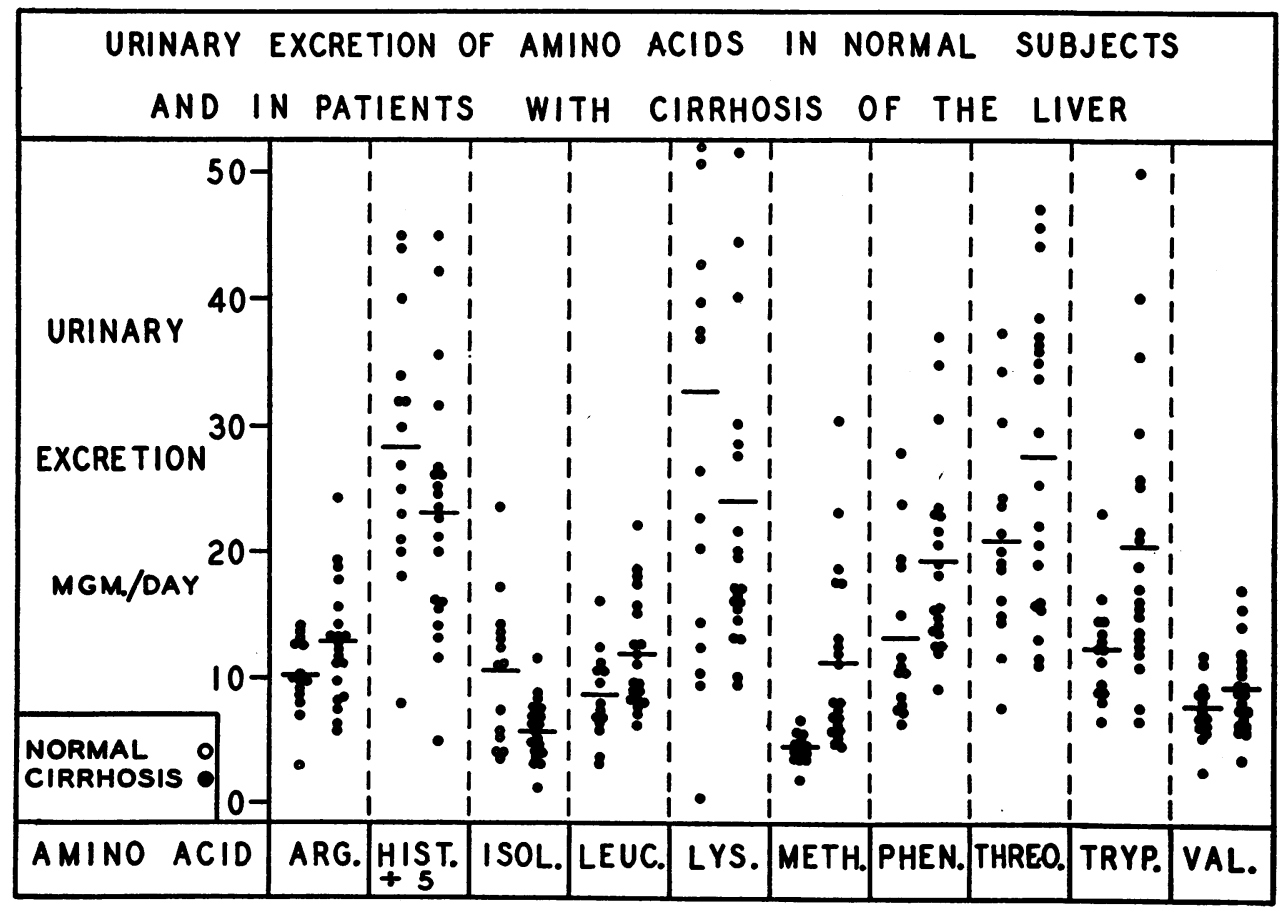

Fig. 1. The Horizontal Line in Each Column Indicates the Average Daily Urinary Excretion Value for Each Amino Acto 
stant daily diets providing at least 2,800 calories, and 100,75 and $50 \mathrm{gm}$. of protein per day, respectively, for the nine to 36 days of study. The urines were pooled in three day periods and analyzed for their contents of amino acids for the first three or four pools and also for pools 8 and 12 in the case of J. S. A normal adult (T. P.) was studied in an identical manner for 39 days during which he consumed a constant diet providing 3,000 calories and $75 \mathrm{gm}$. of protein daily.

The 24 hour urines were preserved with $10 \mathrm{ml}$. of a 5 to 1 mixture of glacial acetic acid and toluene and refrigeration. Individual amino acid analyses were done by microbiological techniques for the eight amino acids essential for man and for arginine and histidine (9). Plasma and urine alpha amino nitrogen were determined by the gasometric ninhydrin methods described by Van Slyke, McFayden, and Hamilton $(10,11)$. Laboratory tests of liver functions included serum bilirubin concentration (12), bile in the urine (13) and urobilinogen (14), serum albumin concentration (15), thymol turbidity $(16,17)$ and flocculation, and retention of intravenously administered bromsulphalein ( $5 \mathrm{mgm}$. per kilogram of body weight at 45 minutes) (18).

\section{RESULTS}

\section{Urinary excretion of the 10 "essential" amino acids}

The daily excretion of each of the ten "essential" amino acids in each of the 20 patients with cirrhosis of the liver is compared to that of fourteen normal individuals presented in Table II and in Figure 1. The daily protein intake of these patients varied from 0 (0.2 gm. of nitrogen) to 125 gm. Sixteen of the twenty patients were consuming either 50,75 , or $100 \mathrm{gm}$. of protein per day, which approximates a normal intake. All patients consuming $50 \mathrm{gm}$. or more of protein daily were in positive nitrogen balance. The results (Figure 1) show a fairly wide scattering above and below the average values for patients and the normal controls. In most instances this scattering was greater for the patients. The average urinary excretion of each amino acid was slightly greater for the patients than for the normal individuals in the case of seven of the amino acids (arginine, leucine, methionine, phenylalanine, threonine, tryptophan,
TABLE II

Urinary excretion of amino acids in patients with cirrhosis of the liver and in normal adults (mgm. day)

\begin{tabular}{|c|c|c|c|c|}
\hline & \multicolumn{2}{|c|}{ Cirrhosis of liver } & \multicolumn{2}{|c|}{ Normal adults } \\
\hline \multirow[t]{2}{*}{ No. subjects. } & \multicolumn{2}{|c|}{20} & \multicolumn{2}{|c|}{14} \\
\hline & Range & Ave. & Range & Ave. \\
\hline $\begin{array}{l}\text { Dietary protein intake, } \\
\mathbf{g m} . / \text { day ............. }\end{array}$ & $0-125$ & 66 & $55-125$ & 77 \\
\hline $\begin{array}{l}\text { Arginine } \\
\text { Histidine } \\
\text { Isoleucine } \\
\text { Leucine } \\
\text { Lysine } \\
\text { Methionine } \\
\text { Phenylalanine } \\
\text { Threonine } \\
\text { Tryptophan } \\
\text { Valine }\end{array}$ & \begin{tabular}{|r|}
$5.8-24.4$ \\
$25-225$ \\
$1.2-11.6$ \\
$6.4-22.2$ \\
$9.7-90.5$ \\
$4.1-30.5$ \\
$9.2-37.4$ \\
$11.7-47.1$ \\
$6.9-50.2$ \\
$3.6-17.2$
\end{tabular} & $\begin{array}{r}12.8 \\
116 \\
5.8 \\
12.0 \\
24.2 \\
11.4 \\
19.4 \\
27.8 \\
20.6 \\
9.5\end{array}$ & $\begin{array}{c}3.0-14.0 \\
38-222 \\
3.8-23.6 \\
3.3-16.2 \\
0-100 \\
2.0-6.8 \\
6.6-28.0 \\
7.7-37.5 \\
6.8-25.4 \\
2.7-11.9\end{array}$ & $\begin{aligned} 10.2 \\
142 \\
10.6 \\
8.7 \\
32.9 \\
4.6 \\
13.4 \\
21.1 \\
12.5 \\
7.8\end{aligned}$ \\
\hline Total & $146-483$ & 259.5 & $115-430$ & 263.3 \\
\hline
\end{tabular}

and valine) but was decreased in three (histidine, isoleucine, and lysine). The overlap between patients and controls, however, was so great that little significance can be attached to differences in the averaged values except in the cases of methionine, of tryptophan, and of isoleucine. In the case of methionine, more than half of the daily determinations in the patients were above the highest value found for the controls, and in some instances was increased five to six times the normal average of $4.6 \mathrm{mgm}$. daily. The average daily excretion of tryptophan was almost twice that observed in the control subjects, and in six instances was from two

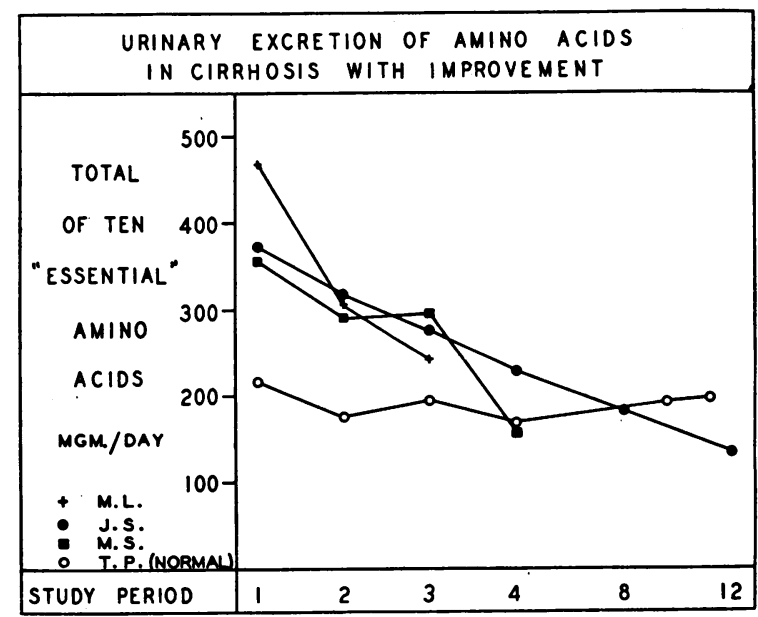

FIG. 2 
TABLE III

Effect of dictary protein intake on the urinary excretion of "essential" amino acids (mgm./day) in patients with cirrhosis of the liver and in a normal adult

\begin{tabular}{|c|c|c|c|c|c|c|c|c|c|c|c|c|}
\hline \multirow{2}{*}{$\begin{array}{l}\text { Patient } \ldots \ldots \ldots \\
\text { Dietary protein, gm./day } \ldots \ldots \ldots\end{array}$} & \multicolumn{2}{|c|}{ F. C. } & \multicolumn{2}{|c|}{ R. H. } & \multicolumn{2}{|c|}{ A. C. } & \multicolumn{3}{|c|}{ J. M. } & \multicolumn{3}{|c|}{ B. S.* (normal) } \\
\hline & 0 & 100 & 25 & 75 & 100 & 150 & 50 & 75 & 100 & 0 & 75 & 150 \\
\hline $\begin{array}{l}\text { Arginine } \\
\text { Histidine } \\
\text { Isoleucine } \\
\text { Leucine } \\
\text { Lysine } \\
\text { Methionine } \\
\text { Phenylalanine } \\
\text { Threonine } \\
\text { Tryptophan } \\
\text { Valine }\end{array}$ & $\begin{aligned} 14.8 \\
99 \\
4.3 \\
9.1 \\
17.2 \\
3.5 \\
15.3 \\
13.9 \\
4.5 \\
13.0\end{aligned}$ & $\begin{array}{r}16.4 \\
74 \\
9.2 \\
13.0 \\
25.0 \\
6.7 \\
13.7 \\
17.3 \\
11.2 \\
15.4\end{array}$ & $\begin{array}{r}14.3 \\
79 \\
4.8 \\
11.2 \\
20.5 \\
17.3 \\
11.2 \\
25.2 \\
14.6 \\
9.8\end{array}$ & $\begin{array}{r}13.8 \\
121 \\
4.2 \\
6.6 \\
19.0 \\
8.1 \\
13.8 \\
21.8 \\
23.7 \\
7.6\end{array}$ & $\begin{array}{r}12.9 \\
115 \\
9.2 \\
18.6 \\
27.5 \\
13.4 \\
28.9 \\
37.5 \\
19.6 \\
11.1\end{array}$ & $\begin{array}{r}8.5 \\
156 \\
6.0 \\
11.6 \\
12.2 \\
25.0 \\
21.9 \\
28.0 \\
22.4 \\
13.0\end{array}$ & $\begin{array}{r}10.6 \\
74 \\
7.7 \\
7.9 \\
13.7 \\
5.1 \\
14.8 \\
19.6 \\
22.3 \\
10.1\end{array}$ & $\begin{array}{r}7.7 \\
129 \\
7.1 \\
11.6 \\
17.0 \\
8.2 \\
24.7 \\
25.3 \\
31.5 \\
9.0\end{array}$ & $\begin{array}{r}10.4 \\
237 \\
6.6 \\
12.0 \\
19.9 \\
8.4 \\
22.0 \\
29.8 \\
33.6 \\
20.7\end{array}$ & $\begin{array}{r}7.0 \\
65 \\
13.5 \\
9.7 \\
11.8 \\
2.8 \\
10.9 \\
14.8 \\
15.8 \\
9.0\end{array}$ & $\begin{array}{r}10.1 \\
99 \\
14.4 \\
11.3 \\
12.5 \\
4.0 \\
15.1 \\
18.9 \\
23.4 \\
11.9\end{array}$ & $\begin{array}{r}8.6 \\
140 \\
16.1 \\
12.9 \\
11.4 \\
4.7 \\
15.9 \\
20.1 \\
27.4 \\
13.7\end{array}$ \\
\hline Total & 194.6 & 201.9 & 208.9 & 239.6 & 293.7 & 304.6 & 185.8 & 271.1 & 400.4 & 160.3 & 220.9 & 270.8 \\
\hline
\end{tabular}

* See reference 19 .

to four times the normal average of $12.5 \mathrm{mgm}$. daily. The average daily excretion of isoleucine by the patients was about one-half that noted in the control group, and all but one of the 20 patients with cirrhosis excreted less of this amino acid than the average value found for the normal subjects.

\section{Effect of dietary protein intake upon urinary amino acid excretion}

The urinary excretion of amino acids was determined in four of the patients during successive periods in which increases in dietary protein intake were made (Table III). The excretions of amino acids in these patients with liver disease are compared with those previously observed in a normal adult maintained on diets of various protein intakes (19). Although alterations in the quantity of dietary protein consumed was accompanied by variations in the urinary excretion of amino acids in the four patients, they were comparable in magnitude to those in the normal individual. Large increases in the dietary protein intake were not accompanied by the urinary wastage of large quantities of these amino acids.

\section{Effect of improvement in liver diseases upon urinary excretion of amino acids}

The urinary excretion of amino acids was followed during improvement in severe active liver disease in three patients (M. L., J. S., M. S.), Figure 2 and Table IV. The diet of each patient was constant throughout these studies and pro- vided 50, 75, and $100 \mathrm{gm}$. of protein daily, respectively. Each metabolic period consisted of three days during which the 24 hour urine collections were pooled prior to analysis. Distinct clinical improvement occurred between the successive periods. The excretion of the total of the ten "essential" amino acids is shown in Figure 2 and of the changes in excretion in the individual amino acids in Table IV. The urinary excretion of the total of the ten "essential" amino acids decreased for each of the three patients as improvement occurred. A similar decrease in the urinary excretion of the individual amino acids toward or to normal is demonstrated.

Data obtained on a normal subject (T. P.) maintained on a constant diet providing $75 \mathrm{gm}$. of protein daily are also included. This subject was studied for a comparable period of time, and the specimens assayed were collected, stored and handled in all respects in a manner identical to those obtained from the patients with liver disease. No decrease in the urinary excretion of the total of the ten essential amino acids or of the individual amino acids was found. The urinary excretion of these amino acids, in fact, remained quite constant during this control study. In addition to pointing out a difference in the urinary excretion of amino acids in the patients with hepatic cirrhosis as compared to the normal individual, the assay results on the "normal" specimens indicate that the decrease observed in the patients is not due to hydrolysis of bound amino acids occurring in the specimens during storage. 


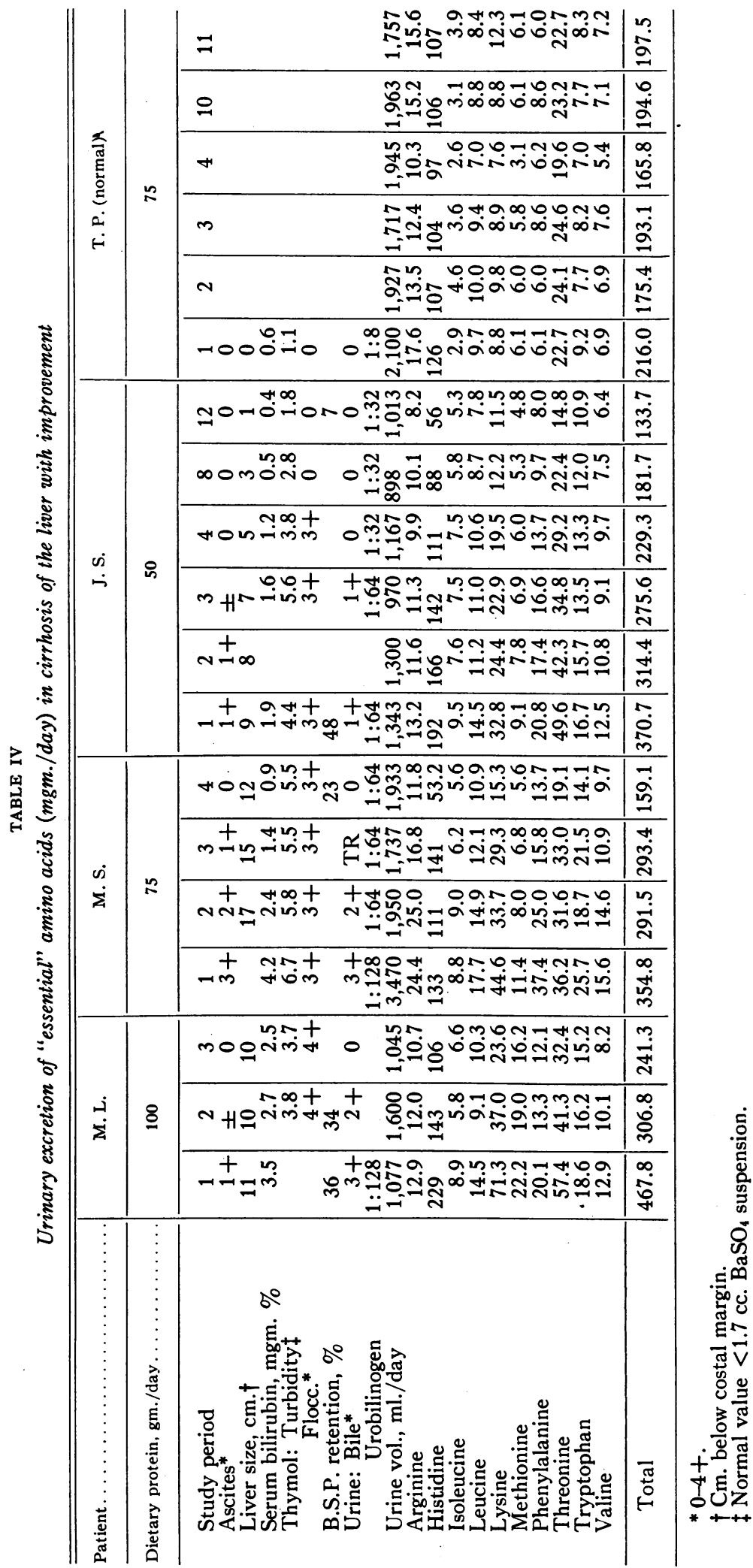


(All assays were done at the completion of each study, at which time the initial specimen obtained had been stored for several weeks.)

\section{DISCUSSION}

The results presented indicate that the urinary excretion of each of the ten "essential" amino acids in patients with cirrhosis of the liver does not differ markedly in quantity from that observed in normal individuals maintained on comparable diets. Likewise, the pattern of the amino acids excreted was comparable for the two groups studied. The values obtained in the patients with liver disease were somewhat more variable than the values in the normal individuals. The average excretion values for seven of the amino acids (arginine, leucine, methionine, phenylalanine, threonine, tryptophan, and valine) were slightly higher in the patients than in the normal subjects, whereas the average excretion of three of the amino acids (histidine, isoleucine, and lysine) were slightly lower in the patient group. An increased urinary excretion of methionine and of tryptophan and a decreased excretion of isoleucine by the patients with liver disease were the most marked deviations from the normal noted. These results confirm and extend the observations concerning the individual amino acid excretion previously reported from this laboratory (1) and by others (2).

It does not seem likely that the increase in urinary amino acid excretion observed in these patients occurs in large enough quantity to be nutritionally significant or to increase the requirement for these amino acids. In the case of methionine, which is excreted in greatest excess, the figure again does not implicate this amino acid as a limiting one. Moreover, supplements of methionine (and choline) do not enhance the positive nitrogen balance of patients with cirrhosis of the liver (20). The failure to detect gross deviations from the normal urine amino acid excretion in these patients does not imply that the intermediary metabolism of each of these amino acids proceeds normally. In fact, abnormalities in the intermediary metabolism of methionine have been demonstrated in patients with liver disease (6).

The significance of the altered amino acid excretion of these patients is not at once apparent. Elevated plasma concentrations of amino acids presumably do not account for this. In a series
TABLE V

Plasma and urine alpha amino nitrogen in patients with cirrhosis of the liver and in normal adults

\begin{tabular}{l|c|c}
\hline \hline & $\begin{array}{c}\text { Cirrhotic } \\
\text { patients }\end{array}$ & $\begin{array}{c}\text { Normal } \\
\text { adults }\end{array}$ \\
\cline { 2 - 3 } & 10 & \\
Plasma: mgm./100 ml. & $10.7-4.5$ & $\begin{array}{c}3.9-4.5 \\
\text { No. subjects } \\
\text { Range }\end{array}$ \\
$\begin{array}{l}\text { Average } \\
\text { Urine: mgm./day } \\
\text { No. subjects }\end{array}$ & 3.8 & 3.7 \\
$\begin{array}{l}\text { Range } \\
\text { Average }\end{array}$ & 15 & 10 \\
& $84-258$ & $118-199$ \\
& 171 & 152 \\
\hline
\end{tabular}

of ten patients with severe liver disease, the average plasma alpha amino acid nitrogen concentration was $3.8 \mathrm{mgm}$. per $100 \mathrm{cc}$. (range 2.7 to 4.5 ) as compared to that for 35 normal individuals of 3.7 mgm. per $100 \mathrm{cc}$. (range 2.9 to 4.5 ) (Table V). Slight reductions in the renal threshold for amino acids, or a continuously elevated plasma amino acid concentration not great enough to be reflected in determinations of the plasma alpha amino nitrogen concentration, constitute another possible explanation for the aminoaciduria. An elevation of plasma methionine concentration has, for example, been observed (6).

Aminoaciduria occurs in Wilson's disease (hepato-lenticular degeneration) and is much greater in quantity than that of the patients reported here $(21,22)$. Investigations led to the conclusion that an alteration in renal excretion best accounted for the abnormality (22). The pathological changes in the liver in the patients with Wilson's disease studied were usually much milder than in the patients with cirrhosis of the liver, so that, although it is possible that the aminoaciduria of the two diseases are related, that occurring in the former condition cannot be attributed to accompanying hepatic cirrhosis.

Since the protein intakes of the patients studied were in most instances within the range of that for the normal adults, forced protein feeding was not the cause of the slight increases in urinary amino acid excretion. It was concluded from a previous study of a normal adult that a large proportion of the amino acids excreted in the urine were "endogenous," and not related to food intake (19). The findings in the patients were comparable to those in the normal adult receiving diets of varied protein contents. 
A progressive diminution in the urinary excretion of amino acids was observed in some patients during improvement in their disease as evidenced clinically and by laboratory tests of liver function. In some instances urinary excretion values which were distinctly elevated returned to well within the normal range. This phenomenon, which has also been observed by others (2), may explain, in part at least, the greater variation noted in the amino acid excretion of the patients with liver disease than of the normal subjects, since this is influenced more by the severity and stage of the patient's disease than by the dietary protein intake. The nutritional implication of these observations is not apparent, but suggests a more efficient utilization of amino acids with improved liver function. Whether the progressive decrease in amino acid excretion noted is unique in patients with liver disease or also occurs in patients recovering from various other illnesses has not been determined.

Gross abnormalities in the urinary excretion of "essential" amino acids by patients with cirrhosis of the liver were not found in the present study or in previous studies. The metabolism of the socalled "non-essential" amino acids, however, has received little attention in these patients. It is conceivable that any limitations of protein synthesis occurring in patients with liver disease may be attributable to a limited ability of such patients to synthesize amino acids. Therefore, the possibility exists that an amino acid which is "non-essential" for normal man may be "essential" for the patient with hepatic disease in order to insure maximal body protein synthesis and repletion in this disease state.

\section{SUMMARY AND CONCLUSIONS}

The urinary excretion of the eight amino acids essential for adult man and of arginine and histidine were determined microbiologically in 20 patients with cirrhosis of the liver and in 14 normal individuals maintained on comparable conditions of study. In selected metabolic studies the effect of increases in dietary protein intake, and in other studies the effect of the severity of the liver disease upon the urinary excretion of these amino acids, was determined.

The results of these studies indicate:
1. The urinary excretion of the eight amino acids essential for man and of arginine and histidine does not differ markedly in quantity, or in pattern, in the patients with cirrhosis of the liver when compared to normal individuals.

2. The average excretion values for arginine, leucine, methionine, phenylalanine, threonine, tryptophan, and valine were slightly higher in the patient group than in the control group, and those for histidine, isoleucine, and lysine were slightly lower.

3. An increased urinary excretion of methionine and of tryptophan, and a decreased excretion of isoleucine by the patients were the most marked deviations from the normal.

4. Large increases in the quantity of protein consumed by four of the patients did not result in the urinary wastage of amino acids.

5. Improvement in liver disease in three patients was accompanied by progressive decreases in the urinary excretion of these amino acids.

6. It is concluded that alterations in the urinary excretion of amino acids by patients with cirrhosis of the liver depend more upon the activity of the patient's disease than upon the dietary protein intake.

\section{ACKNOWLEDGMENTS}

The authors wish to thank the Misses Elaine Hirshberg, Leonora DiCarli, and Alice Ballou for technical assistance and the Misses Kathleen Clinton and Barbara Wolfe for preparing and calculating the diets used.

\section{REFERENCES}

1. Eckhardt, R. D., Cooper, A. M., Faloon, W. W., and Davidson, C. S., The urinary excretion of amino acids in man. Tr. New York Acad. Sc., 1948, 10, 284.

2. Dunn, M. S., Akawaie, S., Yen, H. L., and Martin, H. E., Urinary excretion of amino acids in liver disease. J. Clin. Invest., 1950, 29, 302.

3. Frerichs, F. T., and Staedeler, G., Offenes Schreiben and den Herrn. Hofrath Dr. Oppolzer in Wien. Wien med. Wchnschr., 1854, 4, 465.

Frerichs, F. T., and Staedeler, G., Weiterer Beiträge zur Lehre vom Stoffwandel. Arch. anat. physiol. wissensch. Med., 1856, pp. 37.

Cited by Lichtman, S. S., Diseases of the Liver, Gallbladder and Bile Ducts, second edition, Philadelphia, Lea \& Febiger, 1949, p. 195.

4. Lichtman, S. S., Origin and significance of tyrosinuria in disease of the liver. Arch. Int. Med., 1934, 53, 680 . 
5. Bernhart, F. W., and Schneider, R. W., A new test of liver function-tyrosine tolerance test. Am. J. M. Sc., 1943, 205, 636.

6. Kinsell, L. W., Harper, H. A., Barton, H. C., Hutchin, M. E., and Hess, J. R., Studies in methionine and sulfur metabolism. I. The fate of intravenously administered methionine in normal individuals and in patients with liver damage. J. Clin. Invest., 1948, 27, 677.

7. Hořejší, J., Mecl, A., and Spisarov́a, J., The metabolism of amino acids and liver functions (an experimental and clinical study). Acta Med. Scandinav., 1938, 96, 217.

8. Rose, W. C., Amino acid requirements of man. Federation Proc., 1949, 8, 546.

9. Stokes, J. L., Gunness, M., Dwyer, I. M., and Caswell, M. C., Microbiological methods for the determination of amino acids. II. A uniform assay for the ten essential amino acids. J. Biol. Chem., $1945,160,35$.

10. Hamilton, P. B., and Van Slyke, D. D., The gasometric determination of free amino acids in blood filtrates by the ninhydrin-carbon dioxide method. J. Biol. Chem., 1943, 150, 231.

11. VanSlyke, D. D., MacFadyen, D. A., and Hamilton, P. B., The gasometric determination of amino acids in urine by the ninhydrin-carbon dioxide method. J. Biol. Chem., 1943, 150, 251.

12. Ducci, H., and Watson, C. J., The quantitative determination of the serum bilirubin with special reference to the prompt-reacting and the chloroformsoluble types. J. Lab. \& Clin. Med., 1945, 30, 293.

13. Watson, C. J., and Hawkinson, V., Semiquantitative estimation of bilirubin in the urine by means of the barium-strip modification of Harrison's test. J. Lab. \& Clin. Med., 1946, 31, 914.

14. Wallace, G. B., and Diamond, J. S., The significance of urobilogen in the urine as a test for liver function, with a description of a simple quantitative method for its estimation. Arch. Int. Med., 1925, 35, 698.

15. Howe, P. E., The use of sodium sulfate as the globulin precipitant in the determination of proteins in blood. J. Biol. Chem., 1921, 49, 93.

16. Maclagan, N. F., The thymol turbidity test as an indicator of liver dysfunction. Brit. J. Exper. Path., 1944, 25, 234.

17. Ley, A. B., Lewis, J. H., and Davidson, C. S., The quantitative determination of the thymol turbidity reaction of serum. J. Lab. \& Clin. Med., 1946, 31, 910.

18. Mateer, J. G., Baltz, J. I., Marion, D. F., and MacMillan, J. M., Liver function tests. A general evaluation of liver function tests and an appraisal of the comparative sensitivity and reliability of the newer tests, with particular emphasis on the cephalin-cholesterol flocculation test, the intravenous hippuric acid test and an improved bromsulphalein test with a new normal standard. J. A. M. A., 1943, 121, 723.

19. Eckhardt, R. D., and Davidson, C. S., Urinary excretion of amino acids by a normal adult receiving diets of varied protein content. J. Biol. Chem., 1949, 177, 687.

20. Gabuzda, G. J., Jr., Eckhardt, R. D., and Davidson, C. S., Effect of choline and methionine, testosterone propionate and dietary protein on nitrogen balance in patients with liver disease. J. Clin. Invest., 1950, 29, 566.

21. Uzman, L., and Denny-Brown, D., Amino-aciduria in hepato-lenticular degeneration (Wilson's disease). Am. J. M. Sc., 1948, 215, 599.

22. Cooper, A. M., Eckhardt, R. D., Faloon, W. W., and Davidson, C. S., Investigation of the aminoaciduria of Wilson's disease (hepatolenticular degeneration) : Demonstration of a defect in renal function. J. Clin. Invest., 1950, 29, 265. 